\title{
Research on the Construction Mode of E-commerce Innovation and Entrepreneurship Logistics Management Talent Training System under the "Internet+" Form
}

\author{
Liu Li and Liu kai \\ Yunnan College of Foreign Affairs \& Foreign Language, Kunming, Yunnan,651700
}

Keywords: Internet Plus; E-commerceand logistics; Innovation and Entrepreneurship

\begin{abstract}
Under the background of mass entrepreneurship, mass innovation and "Internet Plus", innovative logistics personnel training is an important strategic measure to promote economic development, scientific and technological progress and international competitiveness. Under the new form of "Internet Plus", the training mode of e-commerce talents in colleges and universities is constantly reformed and innovated to realize the development and market demand of logistics industry. Based on the "Internet Plus" as the background, through the analysis of the status quo of logistics personnel training in the context of e-commerce innovation and entrepreneurship in colleges and universities, by discussing the electronic commerce the feasibility and necessity of creative talents training, we can put forward electricity creative talent cultivation system of building model from the professional characteristics of electricity, curriculum system, teaching in practice and the comprehensive evaluation. These can be a useful reference for solving the e-commerce innovation and entrepreneurship talent training.
\end{abstract}

\section{Introduction}

The current e-commerce industry development in our country is increasingly mature, all e-commerce enterprises are constantly expanding category, optimizing logistics and after-sales service. Meanwhile, they are also actively developing cross-border shopping, sinking channels to develop rural electric business. Under the situation that the comprehensive e-commerce pattern has been determined, we will dig into the vertical e-commerce field and take it as a new promotion point for the development of the e-commerce market. Therefore, e-commerce has begun to become an important driving force for China's knowledge economy and social employment. In addition, the high speed development of today's e-commerce, the increasing demand of electronic commerce , the requirements of low cost, low threshold for network, these prompt electronic business fastly becoming the first choice of the crowd who are trying making innovation and entrepreneurship . At the same time, the development of e-commerce industry and market has accumulated solid strength for innovation and entrepreneurship education of college e-commerce major. In today's "Internet plus" form, building the electrical contractor innovative undertaking personnel training mode gradually becomes an important breakthrough for changing to applied technology university, but it also contributes to high quality, high standard innovative undertaking employment of university students.

\section{The Significance of "Internet plus" E-commerce Innovation and Entrepreneurship Training Model Research}

"Internet plus" e-commerce innovation entrepreneurial talent training should conform to the needs of the development of the industry to create the social value of higher education, actively promote changes in the higher education by using information communication technology and the Internet platform for electronic commerce innovative entrepreneurial talent training mode , under the new form "Internet plus".

Theoretical Significance. Higher education, from quality education, general education to the innovative entrepreneurial education, gradually becomes a common understanding among government officials, the consensus of higher education administrators and teachers, and it is 
welcomed by enterprise and masses of the people. How to combine innovation and entrepreneurship education with the Internet is an important issue in higher education reform, especially in teaching reform. The traditional teaching model has seriously affected the quality of higher education. In the Internet era, education's role is to teach students new learning methods and guide students to learn independently. Innovation and entrepreneurship education is an important form to improve

college students' innovation and entrepreneurship ability, and is the reform direction of higher education talent training mode. The teaching reform of higher education is consistent with the training goal of innovative and entrepreneurial talents, both of which are to cultivate students into high quality applied talents welcomed by the market and enterprises.

Deepen the reform of higher education, highlight the characteristics of college talent training, cultivating high-quality, high-skilled personnel training goal, is to get the e-commerce professional construction, course planning, and teaching research, make the development of students' personal potential it deserves. Therefore, in the new form of "Internet plus", it is imperative to make use of information and communication technology and Internet platform to conduct e-commerce innovation and entrepreneurship education.

Practical Significance. We will formulate the "Internet plus" plan to integrate mobile Internet, cloud computing, big data and the Internet of things with modern manufacturing industries and promote the healthy development of e-commerce. High education of "Internet plus" requires continuous update of education content, continuous reform of education form, and increasingly diversified education evaluation. China's high education is entering a transformation based on information technology.

The curriculum standards, formulated by college and enterprise's cooperation, are fully reflected in professional courses and practical teaching, process orientation, task driving and engineering alternation.The reform of curriculum and practice teaching will be carried out in stages, at different levels and at different levels. Make full use of the resources and advantages of the cooperative enterprise, actively explore the inter-school talent training mode, enhance students' practical ability, and realize the social sharing of education resources. According to the tracking survey of graduates over the years, it is found that the cultivation of innovative and entrepreneurial logistics personnel has achieved certain results in the early exploration. There are still many problems to be studied and explored in many fields of higher education teaching reform.

\section{Feasibility and Necessity of Cultivating Innovative and Entrepreneurial Talents of E-commerce in Colleges and Universities in the Form of "Internet plus"}

Today, in the e-commerce industry development situation of big electric business, big data, the Internet plus, colleges and universities electric business innovation of entrepreneurial logistics personnel cultivation is demanded, under the new normal development of social market economy. Also, an important opportunity for higher vocational college students to their own value realization. According to the actual situation of innovation and entrepreneurship of college students, it is not hard to find that the success rate of entrepreneurship is still not optimistic. As an important base of education, colleges and universities should strengthen education for students' innovation and entrepreneurship. In "Internet plus" form, entrepreneurial talents in colleges and universities to foster innovation is beneficial to correctly guide and promote students' innovative entrepreneurial, alleviate the employment pressure, increase the vitality of social and economic development, at the same time, more conducive to improve the quality of the professional skilled personnel training in colleges and universities , help students grow up and achieve goals in life.

Facing the contradiction and related issues between the electricity industry talent demand and electricity businessmen to cultivate the status quo, in order to further contribute to electricity industry sustained, rapid and sound development, the author thinks that the government departments, universities, enterprises, trade and industry organizations should be more interactive, combining to the talent cultivation and industrial development of e-commerce ideas, explore and practice actively. Universities should actively implement e-commerce professional talent training mode reform, to integrate expertise into industrial development, to achieve academic accomplishment, professional 
standards, industry requirements, employment skills and entrepreneurship, make it accord with the current plan of "mass entrepreneurship, mass innovation", practically producing persons who are meeting the market demand of high quality, high skill talents in China's economic transformation and upgrading era.

\section{Problems in the Training of E-commerce Innovation and Entrepreneurship Talents}

In view of the social needs of e-commerce innovation and entrepreneurship logistics personnel training, although e-commerce majors in various universities have carried out a number of reforms, there are still some problems, as shown in the following aspects.

The Course System of Education for E-commerce Innovation and Entrepreneurship is not Perfect. In order to reflect the content of the innovative undertaking, the existing e-commerce talent cultivation system are on the basis of the original, only cutting out only a few courses and adding several innovative entrepreneurship courses, the new system of innovation in entrepreneurship is not considering the integrity of the talent cultivation system, and the original course lacking of correlation and fusion. Although, to a certain extent, It has increased awareness of the students' innovative undertaking, but quitely different from the requirements of innovative entrepreneurial logistics personnel training.

The Evaluation System of Education is not Perfect. The evaluation index system not only plays an important role in improving teaching quality and realizing curriculum goals, but also help to motivate students to study independently. Most universities, however, the current e-commerce logistics personnel cultivation system are not fully reflect the testing requirements of creative content, in addition, the innovative entrepreneurial talent evaluation system is not sound. As a result, the effect of innovation and entrepreneurship teaching reform is not good enough.

The Practical Link of Education is not Perfect. Innovation and entrepreneurship education focuses on practice. Therefore, scientific and perfect practice is of particular importance. However, there are some problems in the training of e-commerce innovation and entrepreneurship logistics personnels in colleges and universities, including the weak education atmosphere. Relevant departments have insufficient financial support for innovation and entrepreneurship education; The cooperation channels between universities and industries/enterprises are not smooth, resources are not enough, and there is no open cooperation and integrated sharing platform, with lacking of teachers and students innovation and entrepreneurship policy incentives.

\section{University e-commerce innovation and entrepreneurship logistics personnels training system in the form of "Internet plus"}

The training goal of traditional e-commerce professionals is to train business-oriented talents and business technology talents engaged in the management and operation of e-commerce systems for small and medium-sized e-commerce companies. However, under the influence of China's economic transformation and entrepreneurship education, the talent cultivation mode of the e-commerce major in higher vocational education has been given a new connotation - talents capable of using innovative business skills with e-commerce services. The school mainly reconstructs the e-commerce practice system from the following aspects.

Open an Entrepreneurial Education. Establish a content system for entrepreneurship and innovation education for e-commerce professionals and integrate them into talent development programs. The content system of entrepreneurship education includes entrepreneurship awareness, entrepreneurship knowledge, and skills and entrepreneurship practices. Determine the establishment of basic documents such as teaching documents, teachers, teaching conditions, assessment and analysis, project teaching schedule, etc. of entrepreneurship education, build instructional content according to the law of professional competence development, and cultivate students' entrepreneurial innovation capabilities.

Innovate Teaching Methods to Stimulate Students' Innovative Ability. Teaching methods play an important role in inspiring students' innovative ability. For the goal of e-commerce 
innovation and entrepreneurial logistics talents, colleges and universities should boldly innovate teaching methods and teaching methods, realize the transformation of teaching subjects from teachers to students, and inspire students' thirst for knowledge and creativity to fully mobilize students' self-learning ability. Through various means such as case analysis, program exploration, and teamwork, the school will focus on practical and practical "second class" education to comprehensively cultivate students' abilities and qualities in innovation and entrepreneurship.

Building an E-commerce Professional Innovation and Business Practice Platform. Cultivating students' innovative spirit and entrepreneurial ability is the core task of e-commerce professional innovation and entrepreneurship education. To this end, colleges and universities should take the following measures to actively establish the trinity of off-campus innovation and entrepreneurship training bases for production, learning, and research. Colleges and universities can independently establish or join social forces to establish off-campus practice bases, college students' business startup parks, and innovation and entrepreneurship incubation bases, and organize students to innovation entrepreneurial experience, promotes the landing and transformation of college students' innovation and entrepreneurship projects, and effectively improves college students' innovation and entrepreneurship.

Establish a Teaching Platform for Innovation and Entrepreneurship Practice, and Optimize the Practice Teaching System inside and outside the School. Under the "Internet Plus" pattern, the school simulation training should be combined with the e-commerce innovation and entrepreneurship practice to form a distinctive teaching system with distinctive features, levels and progressiveness, and to improve students' professional application ability and creative design ability as much as possible. At the same time, E-Commerce Enterprises and Logistics Enterprises have jointly established E-Commerce Innovation and Entrepreneurship Studios, encouraging teachers and students to jointly create a company, establishing e-commerce innovation and entrepreneurial talents incubator bases that are collaboratively developed with enterprises, and building an on-campus practical teaching platform for e-commerce innovation and entrepreneurship development system. In addition, the second classroom activity was actively set up, and through the measures of "To promote education by competition, to promote learning by competition, to promote examination by competition", the students' cultural quality and professional skills will be comprehensively improved. The off-campus practical teaching system is composed of two parts, online and offline. The online practice teaching system mainly uses the internet as a medium to develop and create an online professional e-commerce training platform.

To Build a Faculty with Innovation and Entrepreneurial Guidance. The innovation and entrepreneurship training of e-commerce and logistics professionals urgently needs to the instruct teachers to continuously improve their own practical innovation capabilities. Professional teachers in-depth training in front-line enterprises, hire entrepreneurs, successful entrepreneurs as part-time teachers, guide students to improve entrepreneurial skills, and provide a solid guarantee for the reform of e-commerce entrepreneurship practice teaching.

\section{Summary}

In today's "Internet Plus" e-commerce industry development, e-commerce professionals in innovation and entrepreneurship training must adhere to the guiding principle of "comprehensive quality, professional skills, entrepreneurial and employment-oriented" and combine the needs of e-commerce industry talents. Features, make full use of the space advantages of the Internet, build a talent training model of integration of production and education, work-study, and work-study, develop a modular curriculum system, realize multivariate integration and dynamic optimization, establish innovative entrepreneurship practice teaching platform, and optimize the practice teaching system inside and outside school, to strengthen the comprehensive quality cultivation education, to build a comprehensive evaluation system for talent cultivation quality, to cultivate high-quality electric merchants that meet the market demand, and to serve regional economic construction and social development. 


\section{Acknowledgement}

Finally, the work described in this paper is partially supported by Funded projects of Yunnan Provincial Department of Education in China under Project No.2017ZZX346.

\section{References}

[1] Audretsch D B. Handbook of Research on Innovation and Entrepreneurship Edited by[M]// Handbook of research on innovation and entrepreneurship. Edward Elgar ;, 2011.

[2] Hamdouch A, Depret M H. Green Business and Entrepreneurship[J]. Encyclopedia of Creativity Invention Innovation \& Entrepreneurship, 2013:812-819.

[3] Lingas K. Family businesses and the gender of entrepreneurship[J]. Journal of Innovation \& Entrepreneurship, 2013, 2(1):4.

[4] Huarng K H, Ribeiro-Soriano D E. Developmental management: Theories, methods, and applications in entrepreneurship, innovation, and sensemaking[J]. Journal of Business Research, 2014, 67(5):657-662.

[5] Trimi S, Berbegalmirabent J. Business model innovation in entrepreneurship[J]. International Entrepreneurship \& Management Journal, 2012, 8(4):449-465.

[6] Švarc J, Lažnjak J, Bečić E. The impact of the crisis on the system for promoting innovation and entrepreneurship[J]. 2015.

[7] Li T. Teaching Reforms of Innovation and Entrepreneurship on Application-oriented Undergraduates Majoring in Business English[J]. Journal of Tianjin Sino-German Vocational Technical College, 2016.

[8] Audretsch D B, Kuratko D F, Link A N. Dynamic entrepreneurship and technology-based innovation[J]. Journal of Evolutionary Economics, 2016, 26(3):603-620.

[9] Freiling J. Editorial: Business Model Innovation - A Concept between Organizational Renewal and Industry Transformation[J]. Journal of Entrepreneurship Management \& Innovation, 2015, 11(1):3-10.

[10]Fang Q, School B. Thinking and Practice on the Curriculum Construction of Innovation and Entrepreneurship in Higher Vocational Education[J]. Journal of Baotou Vocational \& Technical College, 2016.

[11]Pisano P, Pironti M, Rieple A. Business Models, Business Strategy and Innovation[J]. Entrepreneurship Research Journal, 2015, 43(2-3):172-94.

[12] Yong L L, Song H H, Xie X Y, et al. "Internet plus" Era of Innovation and Entrepreneurship Students Practice to Enhance the Ability of Research[J]. 2017.

[13]Etzkowitz H. Making a humanities town: knowledge-infused clusters, civic entrepreneurship and civil society in local innovation systems[J]. Triple Helix, 2015, 2(1):1. 